\title{
VERIFICATION AND PROPOSAL OF THE MODIFICATION OF "THE METHOD FOR THE ESTABLISHMENT OF THE EROSION TERMINANT"
}

\author{
M. Šlezingr, P. Pilařová, P. Pelikán, M. Zeleňáková
}

Received: August 22, 2012

\begin{abstract}
ŠLEZINGR, M., PILAŘOVÁ, P., PELIKÁN, P., ZELEŇÁKOVÁ, M.: Verification and proposal of the modification of "The method for the establishment of the erosion terminant". Acta univ. agric. et silvic. Mendel. Brun., 2012, LX, No. 6, pp. 303-308

The aim of the paper is to inform the professional public about a conducted experiment, its results and recommendations for further scientific assessment and practice. The experiment deals with the basis for a proposal of a prognostic method concerning reservoir bank line retreat caused by waves and the related bank erosion. During the experiment we found discrepancies between the assumed (calculated) values of the height level of erosion terminant (the point in the reservoir bank area where the erosion spontaneously stops) and the measured values. Therefore, we have reached the conclusion, which is presented in the paper, leading to a proposal for a modification of the basic equation for the calculation of the erosion terminant.
\end{abstract}

reservoir, bank, waves, erosion, water, stabilisation

The method for the establishment of the erosion terminant is based on the collection of works by Dr. Linhart (1960s), prof. S. Kratochvíl (1960s and 1970s) and works by doc. Šlezingr (Šlezingr, 2002, 2011).

The method deals with the origin and development of bank erosion. The term "erosion terminant" means the point in the cross section of the bank area, where the progress of erosion - i.e. bank line retreat in the place of toe erosion spontaneously stops.

\section{Basic information on the conducted experiment}

In 2002-2011 the method for the establishment of the erosion terminant was verified in detail, both in its original and modified forms (Linhart, 1954; Kratochvíl, 1969; Šlezingr, 2010). During the longterm regular monitoring of selected reservoir banks - considerably damaged by erosion - we found discrepancies between the assumed (calculated) values and the values measured in situ. We compared the results of measuring at three sites at Brno Reservoir (Czech Republic - hereinafter CR), three sites at Bílovec irrigation reservoir (CR), two sites at Vranov Reservoir (CR) and two sites at Liptovská Mara Reservoir (Slovak Republic - hereinafter SR).

First, we would like to present the Method for the Establishment of the Erosion Terminant in the form which was tested by the long-term monitoring (Šlezingr, 2002, 2011).

When calculating the height level (m a.s.l.) of the erosion terminant, we use the following relations:

Basic equation:

$V a=M_{n \max }+0.5 h_{n}+h o+\Delta H$,

where:

Va.........altitude of the assumed toe erosion (m a.s.l.)

$\mathrm{M}_{\mathrm{n} \max }$..the most frequent water level (m a.s.l.)

$\mathrm{h}_{\mathrm{n}}$.........design wave height (m)

ho .......the central line of a wave $(\mathrm{m})$

$\Delta \mathrm{H}$.......the height of water "being driven" by wind (m). 


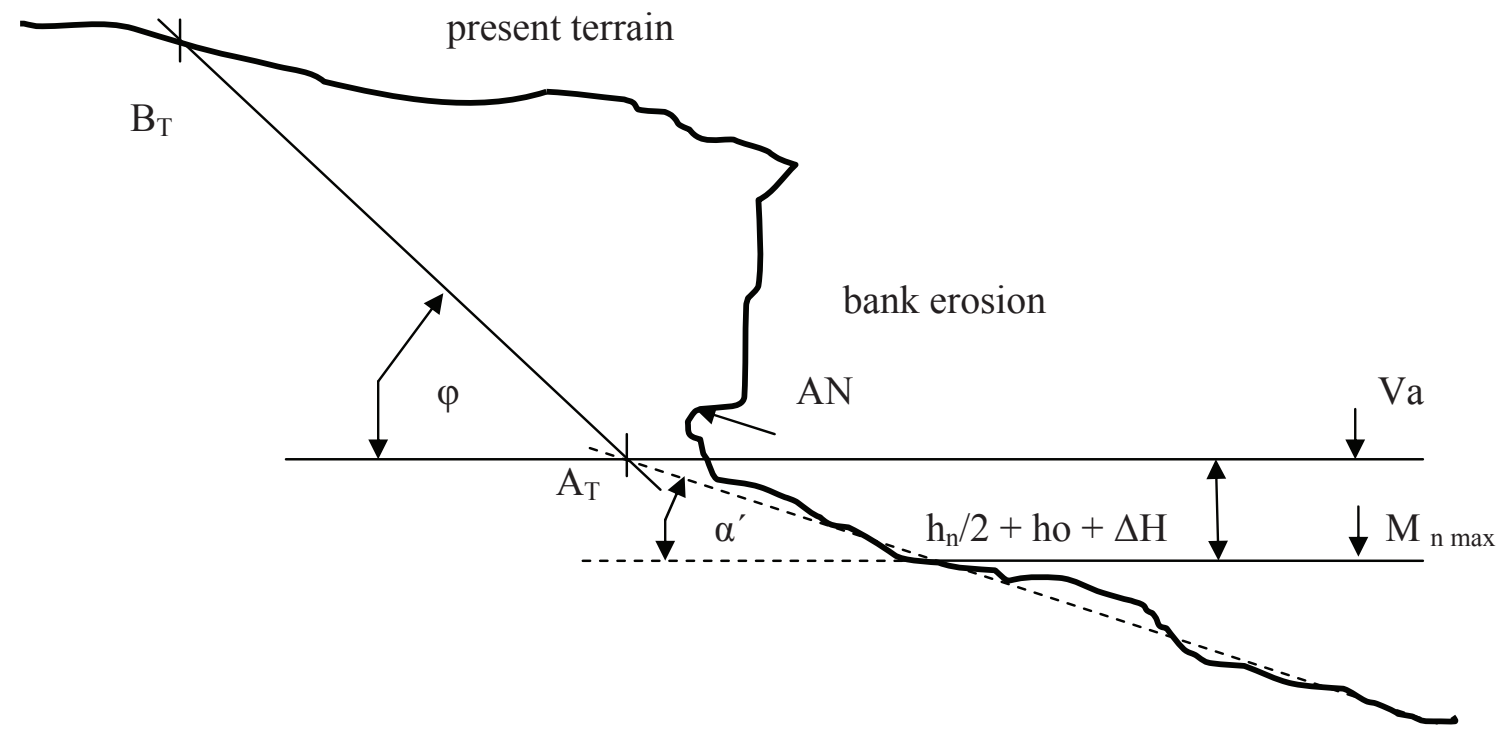

1: The establishment of the erosion terminant according to the modified method (Šlezingr, 2002, 2011)

Legend:

$\mathrm{A}_{\mathrm{T}}$ …............erosion terminant

$\mathrm{B}_{\mathrm{T}}$ …...................

AN ............the height level of the most distant place of the toe erosion (of the erosion notch)

Mn max...the most frequent water level (m a.s.l.)

Va ...............altitude of the toe erosion - determined in compliance with (1) (m a.s.l.)

$\alpha^{\prime}$................slope of the erosion platform $\left(^{\circ}\right)$

$\varphi$................the angle of soil internal friction $\left(^{\circ}\right)$.

The calculation of a design wave height:

$h_{n}=0.0026 \frac{w_{10 v} L_{e f}^{0.47}}{g^{0.53}}$,

where:

$\mathrm{w}_{10 \mathrm{v}}$.. wind velocity at $10 \mathrm{~m}$ above the water surface $(\mathrm{m} / \mathrm{s})$

$\mathrm{L}_{\mathrm{ef}} \ldots . .$. the effective length of wind start-up (if $\mathrm{L}_{\mathrm{ef}}<\mathrm{L}$, instead of $\mathrm{L}_{\text {ef }}$ we take into account $\mathrm{L}$ - the real length of wind start-up) (m)

g ........weight acceleration $\left(\mathrm{ms}^{-2}\right)$

$k_{w}$.........coefficient dependent on wind velocity

for $w_{10 v}<20 \mathrm{~ms}^{-1}$ it is $2.1 .10^{-6}$

for $w_{10 v}<30 \mathrm{~ms}^{-1}$ it is $3.0 .10^{-6}$

for values between 20 and $30 \mathrm{~ms}^{-1}$ the value of

$k_{w}$ is determined by linear interpolation.

The determination of $h_{0}$ is based on Czech Standard ČSN 750255 article 18, p. 2, from which it follows that: $\mathbf{h}_{\mathbf{0}}=\mathbf{0}$.

The calculation of water "being driven" by wind:

$\Delta H=k_{w} \frac{w_{10 v} L_{e f}}{g H} \cos \delta$,

where:

$w_{100} \ldots$ wind velocity at $10 \mathrm{~m}$ above the water surface $\left(\mathrm{ms}^{-1}\right)$

$L_{\epsilon f}$.....the effective length of wind start-up (if $\mathrm{L}_{\mathrm{ef}}<\mathrm{L}$, instead of $\mathrm{L}_{\text {ef }}$ we take into account $\mathrm{L}$ - the real length of wind start-up) (m) g.......... weight acceleration $\left(\mathrm{ms}^{-2}\right)$

$H$....... depth of water in the reservoir (m)

$\delta$.........the angle between the reservoir longitudinal axis and the direction of the wind $\left(^{\circ}\right)$.

Based on the calculation of the presented equation (1), we can determine the value of "Va" for a specific bank area of any reservoir. By comparing the calculated value and the height value of the erosion terminant measured in the observed bank area we should reach a minimum difference. However, when we had compared dozens of measurements and calculations we found a significant deviation in the height level of the erosion terminant reached by calculations and by measuring in the field.

Therefore, we started a detailed analysis of the terms of equation (1). The revealed possible source of the error was the term "ho" - the central line of a wave. The simplification in the sense of its identification with the calm water surface (ČSN 750255 ) is not correct at higher speeds of the wind. Based on most accurate and longest monitoring of the Brno Reservoir we can state that the equation is valid for wind velocity up to about $10 \mathrm{~m} / \mathrm{s}$. However, when calculating the design wave, we often count with higher wind velocities.

After the following necessary study of the appropriate professional literature and many consultations with the leading experts in water management and physics (prof. J. Kratochvíl, prof. M. Chobola, prof. D. Aigner and others), it became obvious that the synchronization of the calculated and measured values will be best feasible 
if we make an experiment based on a long-term measuring in situ, i.e. by measuring at a damaged bank area and implementing the results into (1).

\section{MATERIAL AND METHODS - THE EXPERIMENT}

was conducted at Brno Reservoir (CR), sites Osada, Sokolské koupaliště, Rokle; Bílovec irrigation reservoir (CR), sites Sady I, Sady II and Hráz; Vranov Reservoir (CR), sites Pod Štítary I, Pod Štítary II; and Liptovská Mara Reservoir (SR), sites Dechtáre I, Dechtáre II. The focus of our attention was the difference between the calculated value of the erosion terminant and the height of the most distant and the highest located notch in the toe erosion (in Fig. 1 marked AN).
Tab. I presents the differences between the calculated and the measured values of the erosion terminant in the expression of percentage of a half of the design wave. This measure was used also because the calculation of the design wave height is based on ČSN 750255 and was used in all the cases.

The sum of the percentages (except the value of $12 \%$, which was not taken into account) divided by the number of sites of measuring gives us the average percentage difference between the calculated and the measured values, and it is $41 \%$. Vranov Reservoir, site Pod Štítary I, was not used for the calculation as the toe erosion location could not be reliably determined (the eroded bank partially collapsed in spring 2010) and the measuring in this profile manifests a significant deviation.

The measuring was repeated several times in the profiles (4/2009, 8/2009, 4/2010, 6/2010, 9/2010,

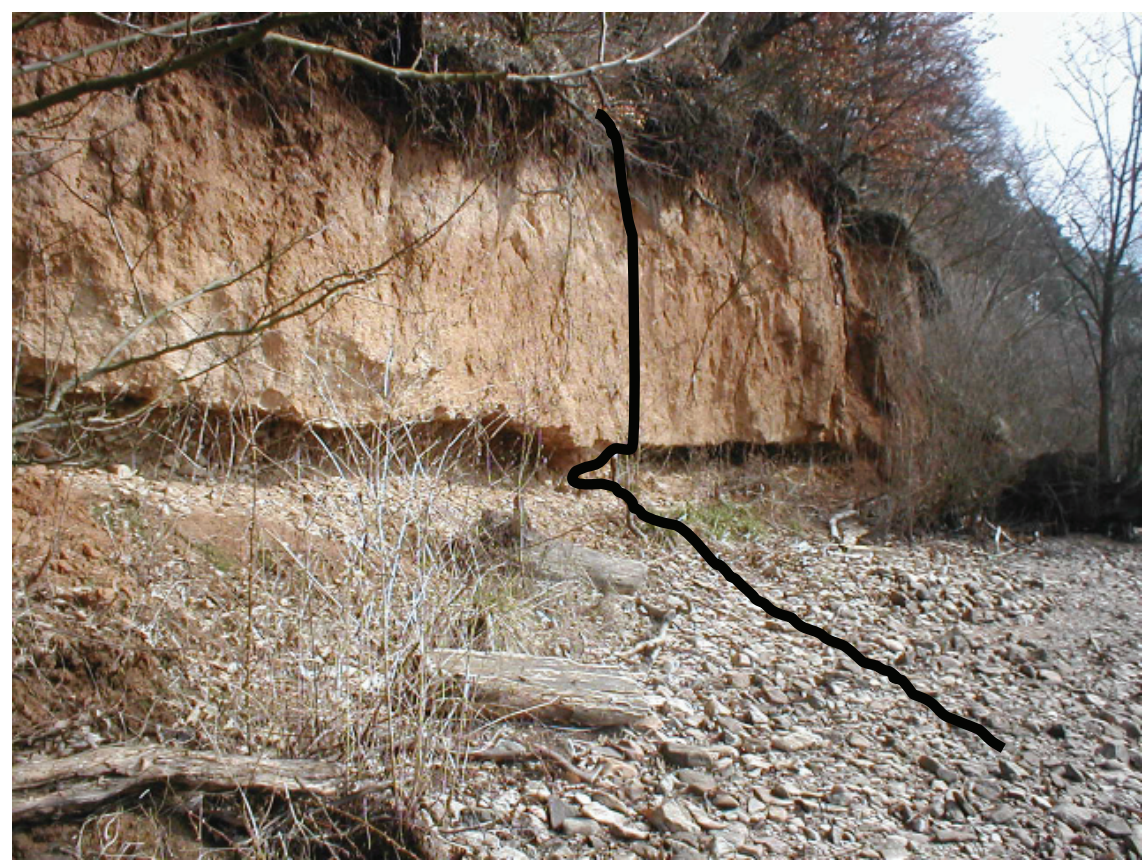

2: The highest located toe erosion notch at Brno Reservoir

(Jedlička, L., Šlezingr, M., 2010)

I: Diferences between the calculated and the measured values

\begin{tabular}{|c|c|}
\hline Site of measuring & $\begin{array}{l}\text { Differences between the calculated and the measured value in \% of a half } \\
\text { of height of } h_{n}\end{array}$ \\
\hline Brno Reservoir, Osada & $40 \%$ \\
\hline Brno Reservoir, Sokolské koupaliště, & $38 \%$ \\
\hline Brno Reservoir, Rokle, & $39 \%$ \\
\hline Bílovec Reservoir, Sady I & $36 \%$ \\
\hline Bílovec Reservoir, Sady II & $42 \%$ \\
\hline Bílovec Reservoir, Hráz, & $43 \%$ \\
\hline Vranov Reservoir, Pod Štítary I & $12 \%$ \\
\hline Vranov Reservoir, Pod Štítary II & $41 \%$ \\
\hline Liptovská Mara Reservoir, Dechtáre I & $44 \%$ \\
\hline Liptovská Mara Reservoir, Dechtáre II & $45 \%$ \\
\hline
\end{tabular}


7/2011) in order to minimize possible errors. For this reason, we consider the measured values of determining character for the formulation of a conclusion following from the above described experiment.

So far, equation (1) has used 0.5 as the value of $h_{n}$. By measuring in situ we found out that in reality the toe erosion notch is $41 \%$ of $0.5 \mathrm{~h}_{\mathrm{n}}$ higher on average. It means, for the calculation it is necessary to add $0.41 \times 0.5$, which equals 0.205 , to the original 0.5 .

The resulting value will thus be $0.5+0.205=0.705$. Newly, we recommend using the modified calculation for the erosion terminant in the following form:

$V a=M_{n \max }+0.705 h_{n}+\Delta H$.

The results of the monitoring presented in this paper show that the previous demands for the modification of the Method for the Establishment of the Erosion Terminant so that the most accurate prediction of the bank line retreat (in Fig. 1 marked as B) would be possible were justified.

\section{RESULTS AND DISCUSSION}

A highly precise establishment of the height of the erosion terminant is important mainly for a prognosis of the bank line retreat in a specific area. Using the value of angle of internal friction " $\varphi$ " of the soil forming the bank of the reservoir, the bank line retreat prognosis can be provided as one of the reasons for the calculation of the erosion terminant. This prognosis is generally of a long-term character, especially regarding the period when point $\mathbf{B}_{\mathrm{T}}$ is reached. However, also reaching point $\mathbf{A}_{\mathrm{T}}$ - the erosion terminant - can be a matter of several decades. The point will not be reached spontaneously in most reservoirs at all or the time when the point is reached will be considerably postponed due to the stabilization measures implemented in the bank areas (Šlezingr, Zeleňáková, 2010; Šlezingr, 2007; Soldo, Oreškovič., Aniskin, 2010).

The modified equation for the determination of $\mathrm{Va}$ is being further verified and we use it for prognoses of the bank line retreat of reservoirs in the Czech Republic.

\section{CONCLUSION}

The issue of bank stabilization can be viewed from several perspectives. First of all, there is the necessity to protect banks against erosion leading to significant damage to the natural bank cover (riparian stands) and origination of erosion walls. Another reason is the considerable loss of forest and agricultural soil - due to bank line retreat. Banks also need to be protected as the fine-grain material is otherwise eroded into the water body, where it sediments and is a cause of a continuous reduction of the reservoir volume. Last but not least, there is an umbrella factor comprising all the above mentioned - the economic perspective.

Therefore, a bank line retreat prognosis is an important step towards bank stability. The results of the prognosis can serve as a basis to determine the areas with the highest risk and thus we can concentrate on those within stabilization measures.

\section{SUMMARY}

The above mentioned modification of the equation determining the height level of $\mathrm{A}_{\mathrm{T}}$ is based on the long-term monitoring of a number of reservoir bank areas.

The method for the establishment of the erosion terminant is a foundation for the bank line retreat prognosis. It follows from the intersection point of the line passing through $\mathrm{A}_{\mathrm{T}}$ and the line starting at this point and continuing in the angle corresponding to the angle of internal friction " $\varphi$ " of the soil forming the reservoir bank. The intersection point of this line with the terrain in a specific cross profile of a bank area is set as the bank line retreat prognosis (in Fig. 1 marked B), assuming that the subsequent long-term erosion activity (in the conditions without anthropogenic interferences) will lead to a stabilized angle of the eroded slope corresponding approximately to the angle of the internal friction of the material it consists of (if the bank is formed from inconsistent soils).

In spite of the necessary degree of simplification, this method provides us with an idea how the bank line retreat will probably proceed in the future and where it will spontaneously stop.

\section{REFERENCES}

BANACH, M. SPANILA T., 2000: Geodynamic evolution of water reserfoir banks, Acta Montana IRSM AS CR, Toruň - Praha.

BAROKOVA, D., ČUBANOVA, L., ŠOLTESZ, A., 2012: Possibilities for Wetland Recreation in the Senianska Depression Using Controlled Flooding,
Journal of Landscape Management, Vol. 3, No. 1 p. 55-60.

GURUKUMBA, K. MUKUPE, H., 1998: Stabilisation of Kariba South bank 1998, XIX kongres ICOLD - přehledná informace. In: Priehradné dni Košice 1998, str. 58.

HRUZA, P., 2003: Optimisation of forest road network under principles of functionally 
integrated forest management, Journal of Forest Science, 49 (9), pp. 439-443.

HUBER, A., 1998: Quantifying impulse wave effect in reservoirs, XIX. kongres ICOLD - přehledná informace. In: Priehradné dni Košice, 1998, str. 60.

JEDLIČKA, L., ŠLEZINGR, M., 2010: Bankside trees and shrubs, Colloquium on Landscape Management Brno MENDELU, 14-17.

KABISCH, K. HAMMERLING, J., 1981: Tuempfel, Teiche und Weiher - Oasen in unserer Landschaft, Leipzig.

KRATOCHVÍL, S., 1969: Parametry větrových vln na přehradní nádrži, Vodohospodárský časopis, 17, 4: 320-337.

LINHART, J., 1954: Intenzita abrazní činnosti hladiny Kníničské přehrady, In: Sborník ČS společnosti zeměpisné, 4, 185-194.

MOORE, D. HUNGER, O., 1998: Experience based on banks fortification structures - Water reservoir. In: Proceedings Eighth International Congres, Vancouver - Canada, pp. 3845-3851.

RODRIGUEZ, E. R., 1996: Vorlesung 1803: Wasserbau und Wasserwirdschaft, Wiesbaden.

RODRIGUEZ, E. R., 1996: Vorlesung 1801: Wasserbau und Wasserwirdschaft, Wiesbaden.

SCHOKLITSCH, A., 1930: Der Wasserbau, Verlag von J. Springer, Wien.

SOLDO, B., OREŠKOVIČ, M., ANISKIN, A., 2010: Example of water waves impact on the bank slope, Journal of Landscape Management, No. 2, 40-43.

SYNKOVÁ, J., 2009: Evaluation of stream stability after revitalisation, Acta Universitatis Agriculturae et Silviculturae Mendelianae Brunensis, 57, 1: 105-113.

SYNKOVÁ, J., 2009: Possibility of utilization of direction construction in river revitalization, Acta Universitatis Agriculturae et Silviculturae Mendelianae Brunensis, 57, 5: 279-284.
ŠLEZINGR, M., ZELEŇÁKOVÁ, M., 2010: Natural processes of the self purification in rivers, Journal of Landscape Management, No. 1, 63-66.

ŠLEZINGR, M., 2002: Bank erosion - prognosis of the retreat of bank line of reservoirs, Journal of hydrology and hydromechanics, Vol. 50, pp. 311319.

ŠLEZINGR, M., 2007: Stabilisation of reservoir banks using an "armoured earth structure", Journal of hydrology and hydromechanics, No. 1.

ŠLEZINGR, M., 2011: Břehová abraze, Folia Universitatis, MENDELU, 174 s., ISBN 978-807375-566-9.

ŠLEZINGR, M., JEDLIČKA, L., 2010: Accompanying vegetation - grassland, Colloquium on Landscape Management Brno, MENDELU, p. 28-30.

ŠOLTÉZS, A., 2007: Water Management in the Medzibodrožie (Bodrogköz) Cross Border River Basin Region - Case Study. In: Water Management and Hydraulic Engineering: Proceedings of 10th International symposium./Croatia, Šibenik, Zagreb: Faculty of Civil Engineering. ISBN 978953-6272-22-8.

ŠOLTÉSZ, A., BAROKOVÁ, D., LÁSZLÓ, L., 2008: Vodstvo Medzibodrožia. In: Život medzi riekami: Monografia krajinného manažmentu Medzibodrožia. Miskolc: Univerzita Miskolc., pp. 29-41, ISBN 9789630642651.

ÚRADNÍČEK, L., ŠLEZINGR, M., 2007: Stabilizace brehui, l. vydání, Akademické nakladatelství CERM Brno, 210 s. ISBN 978-80-7204-550-1.

ZELEŇÁKOVÁ, M., 2009: Vodnéstavby. E-learningová podpora výučby predmetu. CD-rom. 240 s. ISBN 978-80-7041-752-2.

ČSN 750255: Calculate the effects of waves on the construction of water reservoirs.

Address

doc. Dr. Ing. Miloslav Šlezingr, Ústav vodních staveb, Vysoké učení technické v Brně, Žižkova 17, 60200 Brno, Česká republika, Ústav tvorby a ochrany krajiny, Mendelova univerzita v Brně, Zemědělská 1, 61300 Brno, Česká republika, doc. Ing. Martina Zeleňáková, PhD., Ústav budov a prostredia, Technická univerzita v Košiciach, Letná 9, 04200 Košice, Slovenská republika, Ing. Pavla Pilařová, Ing. Petr Pelikán, Ústav tvorby a ochrany krajiny, Mendelova univerzita v Brně, Zemědělská 1, 61300 Brno, Česká republika, e-mail: slezingr.m@fce.vutbr.cz,martina.zelenakova@tuke.sk, pelikanp@seznam,cz 
